\title{
Er Balkan glemt?
}

\section{Af Christian Axboe Nielsen}

Trods alt eksisterer der stadigvæk ret stor tillid til EU på Balkan. Men denne tillid stammer mere fra manglende tiltro til egne politiske, økonomiske og samfundsmæssige ledere end fra tiltro til de højt besungne europæiske værdier. Men EU må holde døren åben for resten af Balkan, samtidig med at det hele tiden gøre det klart, at medlemskab kun kan opnås gennem hårdt arbejde og ved at vedtage og gennemføre omfattende reformer.

Har EU glemt Balkan? Og vil Balkan stadigvæk EU? Disse spørgsmål vil måske forbavse, taget i betragtning at $\mathrm{EU}$ så sent som i 2013 gjorde Kroatien til 28. medlem af Unionen, og at EU fortsat planlægger at indlemme samtlige lande på Balkan, der endnu ikke er medlemmer. Men netop disse provokerende spørgsmål bliver ofte stillet af både forskere, der beskæftiger sig med Balkan, og også af mange borgere i de pågældende lande. I virkeligheden er situationen ikke så dramatisk som de største kritikere af EU påstår, men der er stadigvæk god grund til bekymring, særligt hvad angår de to mest vanskelige cases på Balkan: Bosnien-Hercegovina og Kosovo.

Samtidigt har EU's tiltrækningsevne, som resultat af både interne og eksterne kriser i Unionen, mistet en stor del af den glans, som den havde for kun få år tilbage. Så hvordan betragtes EU i de lande, der endnu ikke har opnået medlemskab i EU, og vil deres medlemskab styrke Unionen i en krævende stund, eller risikerer de nyere medlemmer at få Unionen til at krakelere endnu mere, end det i forvejen er tilfældet?

Først har vi lige brug for en hurtig begrebsmæssig redegørelse. Når der skrives om Balkan her, hentydes der til det tidligere Jugoslavien (Slovenien, Kroatien, Bosnien-Hercegovina, Serbien, Montenegro, Makedonien og Kosovo) samt Rumænien, Bulgarien, Albanien og Grækenland. Heraf har nogle været medlemmer af EU i lang tid - Grækenland - imens andre - Slovenien, Bulgarien, Rumænien og Kroatien - er kommet ind i varmen meget senere. Tyrkiet har også fodfæste på Balkan og en enormt stor historisk, kulturel og også nutidig økonomisk betydning for Balkan. Men forhol-

Christian Axboe Nielsen er historiker og lektor i sydøsteuropæiske studier ved Aarhus Universitet. Han har vidnet som ekspert i flere retssager ved FN's straffedomstol for det tidligere Jugoslavien. Han forsker i Balkanhistorie og skriver p.t. bøger om Jugoslaviens sammenbrud og om politiet og politiets efterretningstjeneste i det socialistiske Jugoslavien. 
det mellem Tyrkiet og EU er et kapitel for sig. Og så kan det lige nævnes, at mange i den nordvestlige del af Balkan især slovenerne og kroaterne - helst ikke vil kendes ved begrebet og foretrækker begrebet Sydøsteuropa - eller sågar insisterer på, at de ikke hører hjemme i hverken af delene. EU foretrækker selv det mærkelige begreb 'Vestbalkan', når de dele af Balkan, der fortsat er uden for EU, omtales.

Nuvel. Uanset de mange heftige kriser og forandringer, der har påvirket Balkan og EU siden begyndelsen af 1990'erne, kan det konstateres, at der både i EU og på Balkan har hersket en ret stærk konsensus om to fundamentale udgangspunkter: Balkan er en geografisk del af Europa, og derfor skal alle Balkanlandene indlemmes i Unionen. Serbien var i mange år eneste meningsfulde undtagelse til denne konsensus, da staten (tidligere som Forbundsrepublikken Jugoslavien og også statsunionen Serbien-Montenegro indtil 2006) havde paria-status og et åbenlyst fjendtligt forhold til EU og Vesten. Situationen ser imidlertid helt anderledes ud i Serbien, men mere om det senere. Den skepsis, der hersker i EU-landene i dag angående Balkan, har således intet med geografiske eller kulturelle argumenter at gøre.

Bosnien-Hercegovina, Montenegro, Serbien, Makedonien og Albanien er de fem stater på Balkan, der endnu ikke er blevet medlemmer af EU. I alle fem stater er der bred enighed på den politiske scene om, at EU-medlemskab er ønskværdigt. Det er fortsat ikke atypisk, at statsministre, præsidenter og udenrigsministre erklærer, at EU-medlemskab er deres staters eller regeringers vigtigste udenrigspolitiske prioritet.

Den eksisterende skepsis skal snare- re ses fra en strukturel vinkel. Allerede efter den store udvidelse mod øst i 2004 og Rumænien og Bulgariens entré i 2007 herskede der mæthed og udmattelse blandt de gamle EU lande mht. videre udvidelse. Dels mente man i Bruxelles, at de to sidstnævnte lande var kommet for hurtigt ind og ikke var tilstrækkeligt modne for EU, dels blev EU efter 2008 finansielt ramt af økonomisk recession og den voksende eurokrise. Derudover var der fortsat gang i den klassiske 'bredere versus dybere' debat i EU, og stigende autoritært styre i Ungarn gjorde det nødvendigt at spørge, om EU nu også havde styr på de "gamle nye" medlemmer fra 2004.

\section{Kroatien}

Kroatien formåede at blive det 28. medlem af EU i 2013, men man kan argumentere for, at medlemskabet i mindst lige så høj grad bekræftede det haltende tempo af udvidelse som det bekræftede længsel efter videre udvidelse. Med sine 4 millioner indbyggere var Kroatien en overkommelig størrelse selv for et overmæt EU. Og havde det ikke været for Kroatiens manglende samarbejde med FN's straffedomstol for det tidligere Jugoslavien (ICTY) og en langvarig grænsestrid med Slovenien, ville Kroatien sandsynligvis have været med i en tidligere udvidelsesrunde. Imidlertid havde gældskrisen allerede fået Der Spiegel - hentydende til Kroatiens geografi - til at spørge, hvorfor EU lige netop nu skulle finde på at sluge en 'giftig croissant'.

Omvendt var både de vigtigste politiske partier i Kroatien og befolkningen blevet klar over, at EU-medlemskab på ingen måde ville være et universalmiddel mod de store politiske og især økonomiske udfordringer, som Kroatien stod 
overfor. Samtidig mente et lille, men højrøstet populistisk mindretal i Kroatien, at det var en fejl for Kroatien at afgive sin suverænitet til EU kun to årtier efter uafhængighed fra det forhadte Jugoslavien. Kroatiens tiltrædelse i sommeren 2013 blev derfor til en meget afdæmpet affære. Mange politiske kommentatorer i Kroatien har siden da undret sig over, hvor lidt landet har forandret sig efter EU-medlemskab. Denne skuffelse undervurderer dog mange af de ganske nyttige administrative og strukturelle forandringer, der blev vedtaget i opløbet til Kroatiens medlemskab. Hvor om alt er, kan det siges, at udviklingen i Kroatien siden medlemskab er med til at præge de dæmpede og realistiske forventninger, som kandidatlandende har til medlemskab.

\section{Serbien}

Som tidligere nævnt var Serbien i 1990'erne uden tvivl det land i Europa, der havde det mest anspændte forhold til EU. Imidlertid sidder der i 2015 i Serbiens parlament ikke ét eneste medlem, der er imod EU-medlemskab. Om end Serbien er en republik med en præsident som statsoverhoved, ledes landet i virkeligheden af en stærk statsminister, Aleksandar Vučić. Denne tidligere ultranationalist har et jerngreb om magten i Serbien og tvinger de nødvendige reformer igennem det serbiske parlament og statsvæsen. Dette gør EU godt tilfreds, men her er det værd at bemærke, at Serbiens målrettede gang mod EU-medlemskab sker på bekostning af principper, der ellers skulle være meget relevante for EU. Der er for eksempel mange i Serbien, der påpeger, at de serbiske medier er mindre frie, end de var under Milošević, eller at Vučić tag på den serbiske stat ville have gjort Milošević misundelig. Landet har p.t. ingen meningsfuld opposition, og med et blik mod nabolandet Ungarn snakkes der om risikoen for en 'Orbánisering' af Serbien. Ligeledes kan det siges, at støtte for EU blandt Serbiens befolkning nok i langt mindre grad har med egentlig entusiasme for europæiske værdier at gøre, og i stedet i langt højere grad giver udtryk for den omfattende klientelisme, der præger Serbien. Kort fortalt er Serbien godt på vej til den situation, som politologer beskriver som 'state capture', hvor ét politisk parti sætter sig så tungt på magten, at demokratiet kvæles.Men så længe at Serbiens regering fører den rigtige politik, skal man lede langt efter kritik af denne situation fra EU's ledere.

Den manglende kritik af Serbien i Bruxelles har også med forholdet mellem Serbien og Kosovo at gøre. Siden krigen i 1999 og Kosovos uafhængighedserklæring i 2008 har Serbien nægtet at anerkende landet, mens 23 ud af 28 EU-medlemmer har anerkendt det. Men under konstant og stædigt pres fra EU, særligt EU's første 'udenrigsminister' Catherine Ashton, blev både Serbien og det næsten lige så modvillige Kosovo kastet ud på dansegulvet. Under EU's opsyn måtte repræsentanter fra de to lande tage de første nænsomme runder sammen. Dansen gik især ud på at opnå enighed på en lang række praktiske spørgsmål omkring gensidig anerkendelse af dokumenter, regler osv. Disse forhandlinger foregik under den illusion, at Serbien ville kunne opnå en forståelse på mange emner af fælles interesse for de to landes borgere uden at anerkende Kosovo.

I virkeligheden kan der tales om en slags krybende de facto anerkendelse af Kosovo fra serbisk side. Uvist er stadigvæk, hvorvidt en endelig afslutning af Serbiens implementering af de $35 \mathrm{ka}$ - 


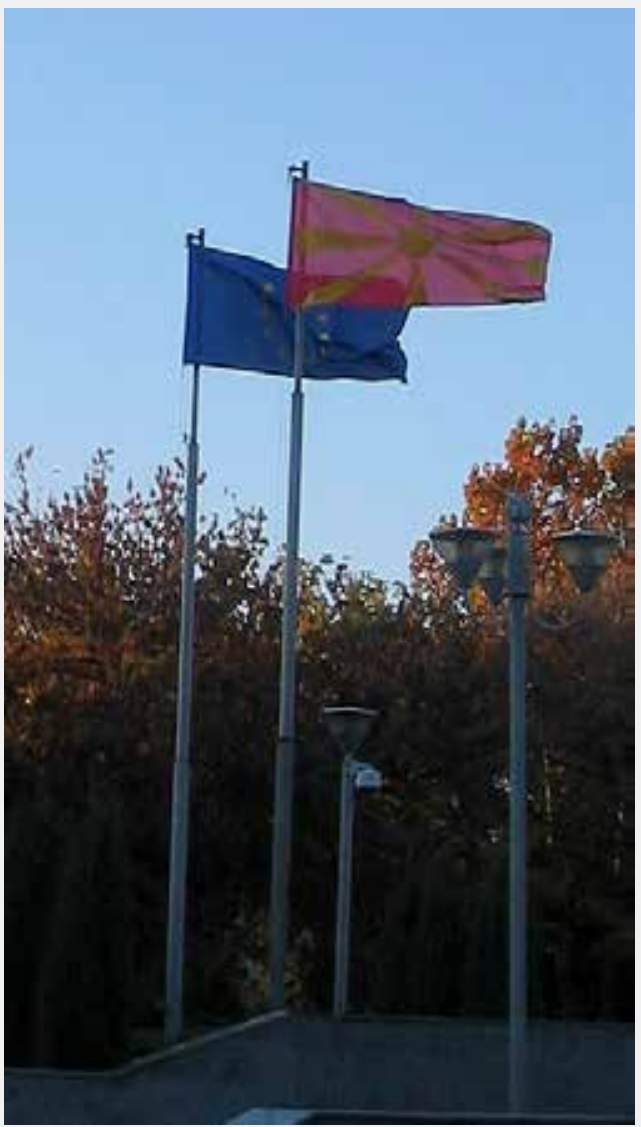

FOTO: Francis Tyers via Wikimedia Commons

Det makedonske flag og EU-flaget vajer side om side uden for en regeringsbygning i Skopje. Makedonien, Albanien, Bosnien-Hercegovina, Montenegro og Serbien er de fem stater på Balkan, der endnu ikke er blevet medlem af EU, men i alle landene er der bred politisk enighed om, at medlemskab er ønskværdigt.

pitler af EU's reglement - acquis communautaire - vil kræve en de jure anerkendelse af Kosovos uafhængighed. Statsminister Vučić lader til at tænke: den tid, den sorg, vel vidende, at der er mange EU-midler at hente, så længe at Serbien viser sig som en pragmatisk partner. På længere sigt er det klart, at det ville være en fejltagelse for EU at tillade Serbien at blive medlem før Kosovo, da dette ville kunne muliggøre et ser- bisk veto - en slags gentagelse af Cyperns medlemskab i 2004.

\section{Kosovo og Montenegro}

Måske overraskende er Kosovo i dag et større problem for EU end Serbien. Kosovos nuværende politisk ledelse vil EU-medlemskab og forstår nødvendigheden af en pragmatisk holdning til Serbien. Imidlertid er Kosovos politiske landskab præget af en stillingskrig mellem regeringspartierne og oppositionspartier, der mener, at de EU-ledte forhandlinger med Serbien er lig med landsforræderi. EU's image har også nyligt taget skade i Kosovo, da EU er i færd med at oprette en ny ad hoc domstol, hvilken ville give mulighed for at retsforfølge Kosovo-albanere, der begik alvorlige forbrydelser under krigen i Kosovo.

Især denne del af samarbejdet med EU er meget upopulært, og det har der været givet udtryk for i 2015 bl.a. gennem brug af tåregasgranater i landets parlament.

Derudover har Kosovo pga. den politiske stillingskrig og en meget svag økonomi præget af tårnhøj arbejdsløshed oplevet massiv udvandring, hvilket har faet EU til at undlade at løfte visumpligt for Kosovos borgere. Vejen til EU-medlemskab bliver lang for Kosovo.

Rettes der et kort blik mod Montenegro, er det på mange måder et land, der især på grund af sin størrelse skulle være en nem mundfuld for EU at sluge. Montenegro er også netop blevet tilbudt medlemskab i NATO. Men udfordringen i Montenegro er, at landet i den grad er præget af state capture, hvilket symboliseres af statsminister Milo Đukanović. Denne kontroversielle politiker har næsten uafbrudt holdt magten i Montenegro siden Jugoslaviens forfald. Omkring ham der opstået et tætvævet og dunkelt 
spindelvæv af klientelisme og organiseret kriminalitet. På grund af Montenegros provestlige politik og beskedne størrelse har landet i længere perioder undgået stor kritik fra EU.

\section{Makedonien}

De seneste begivenheder i Makedonien illustrerer på udmærket vis, hvilke risici det indebærer, hvis EU's opmærksomhed glider væk fra Balkan. Her er der tre sammenflettede problemer. Først har EU meget beklageligt vist sig ikke at være i stand til at styre Grækenland, der, som det eneste EU-medlem, på uforståelig og irrationel vis nægter Makedonien ret til at bruge sit navn i internationale organisationer. Manglende indgreb over for Grækenlands politik har ført til en næsten tragikomisk nationalistisk tvangstænkning i makedonsk politik og kultur, hvor knappe offentlige midler bliver $ø$ dslet bort på nyttesløse statuer af 'makedonske' historiske figurer, hvor disse midler i stedet gerne skulle bruges på landet skrøbelige infrastruktur, sociale ydelser osv.

Den makedonske nationale megalomani har en direkte destabiliserende effekt på det afgørende forhold i Makedonien mellem etniske makedonere og det store og urolige albanske mindretal. Efter en kortvarig krig i 2001 har EU med en betydelig grad af held formået at holde politikere fra de to nationer samlet. Men i 2015 truede situationen med at køre fuldstændig af sporet.

I løbet af foråret bragte socialdemokratiet i oppositionen anklager frem om, at det nationalkonservative regeringsparti systematisk skulle have aflyttet tusindvis af politikere, embedsmænd, journalister og andre. Aflytningsskandalen var kun en del af en større pakke af anklager om omfattende magtmisbrug, og i løbet af foråret og sommeren opstod der en bølge af protester.

Meget vigtigt var disse protester multietniske og illustrerede dermed, at utilfredsheden med regeringen og dens klientelisme var udbredt i hele befolkningen. Da der så pludselig i løbet af sommeren opstod en ildkamp mellem angiveligt albanske separatister og makedonske sikkerhedsstyrker i det nordvestlige Makedonien, mente mange, at denne trussel mod den nationale sikkerhed var iscenesat af statsminister Nikola Gruevski for at trække opmærksomheden væk fra regeringens mange skandaler.

For kritikere af EU, der beskæftiger sig med Balkan, er Makedonien et eksempel på, hvordan EU har sovet i timen. Det er meget svært at få øje på egentlig fremskridt i Makedonien i løbet af de sidste fem år.

EU har ikke været i stand til at gennemtvinge nødvendige reformer eller bremse et stigende autoritært styre fra Gruevskis side, og i den første tid var EU også svær at få øje på, selv da landets politiske landskab blev kastet ud i en dramatisk tvekamp. Da EU's kommissær for udvidelse, Johannes Hahn, omsider rejste til Makedonien, kom han med nogle bemærkninger, der syntes at være et fejlagtigt diplomatisk forsøg på at fordele kritikken blandt oppositionen og regeringen. Om end det til sidst lykkedes Hahn at få parterne til at skrive under på en handlingsplan, faldt denne plan fra hinanden næsten med det samme. Hahn var derfor nødt til at rejse tilbage til Makedonien et par uger senere for at få genstartet forsøget på at redde Makedonien fra afgrunden. Denne plan kan nu siges at være i implementeringsfasen, men det kommer til at kræve meget mere tilsyn 
fra EU's side, hvis planen om frie valg og reformer i 2016 skal blive en succes.

\section{Albanien og Bosnien-Hercegovina}

Albanien er det EU-kandidatland på Balkan, der burde have den nemmeste vej mod medlemskab. Udenrigspolitisk har Albanien gode forhold til de fleste naboer. Den eneste store udfordring er forholdet til Serbien, da Albanien og Serbien til tider skændes omkring Kosovo. I Albanien er befolkningen forholdsvis entusiastisk mht. EU-medlemskab, og EU taler om beskedent men mærkbart fremskridt i implementeringen af de nødvendige reformer. Korruption og reform af justitsvæsenet hører ikke overraskende også i Albanien til de største udfordringer. EU har også krævet mere handling fra Albanien mht. organiseret kriminalitet og smugling af mennesker og narkotika.

Sidst, men ikke mindst når vi frem til Bosnien-Hercegovina, der desværre må betegnes som det mest problematiske tilfælde på Balkan. For nylig var der tyve års jubilæum for Dayton-aftalen, der afsluttede krigen i Bosnien. Denne aftale har på en måde været en fantastisk succes, taget i betragtning at aftalen fik afsluttet en krig, der havde kostet ca. 100.000 menneskeliv og skabt millioner af internt fordrevne og flygtninge. Problemet med Dayton-aftalen er, at den fastfrøs Bosnien stort set som det var opdelt i slutningen af krigen. Med andre ord har der siden $1995 \mathrm{i}$ bred omfang hersket en situation, hvor der er 'negativ fred', altså mangel på bevæbnet konflikt i landet. Den 'positive fred', hvilket ville indebære frivillig og betydelig politisk, økonomisk, social og kulturel samarbejde på tværs af de tidligere konfliktlinjer, udebliver.

Under Dayton fik Bosnien-Hercegovi- na en meget tungt administrativ struktur, præget af en svag central stat, to entiteter, ét distrikt og ti kantoner. Det er en meget stor og meget dyr kransekage, med det resultat at Bosnien er det land i Europa, hvor der bruges flest penge pr. indbygger på statsadministration. Og denne struktur gengiver sig selv gennem en meget indviklet klientelistisk struktur, der kun giver mulighed for fremskridt til dem, der forholder sig ukritisk til denne struktur. Det politiske liv domineres af partier, der erklærer at repræsentere ét af de tre konstitutive folkeslag i Bosnien - bosniakker, serbere og kroater - men som mest af alt er til for at forsørge deres eget parti. Næsten alle politiske beslutninger, selv de mest banale, risikerer derfor at ende i dødvande og nulsumsspil. I 2014 førte denne situation til de første store politiske demonstrationer siden krigen, da frustrationen hos befolkningen i storbyerne omsider kogte over.

EU er massivt til stede i Bosnien, og alle førende bosniske politikere støtter i det mindste deklarativt EU-medlemskab. Ikke desto mindre har landet ikke formået at gøre meningsfulde fremskridt mod de nødvendige reformer i løbet af de sidste otte år. Kort fortalt ønsker førende bosniakkiske politikere, at Dayton skal forkastes til fordel for en stærk og mere centraliseret bosnisk stat. Det er politikerne i den serbiske entitet, Republika Srpska, lodret uenige i. Her truer den førende bosniske serbiske politiker Milorad Dodik i stedet med at afholde en folkeafstemning, der vil bane vej for løsrivelse fra Bosnien.

Endnu mere bekymrende er det, at Dodik nyligt har beordret myndighederne i Republika Srpska til ikke at samarbejde med det nationale politi og den nationale domstol. Dette ligner til forveksling nog- 
For nogle år siden bemærkede The Economist, at hvis EU ikke kom til Balkan, så kunne Eப være sikker på, at Balkan ville komme til Eப - i form af flygtninge, migranter og andre udfordringer.

le af de tiltag, der i sin tid førte til krigen i Bosnien. Set fra dette perspektiv er det noget nær chokerende, at EU i samarbejde med andre internationale aktører ikke har grebet hårdt ind over for Dodik. I stedet fortsætter Dodik med sine provokatoriske ytringer og handlinger. Han har også sat gang i et muligt samarbejde med de bosniske kroater, der ikke helt har kunnet begrave ønsket om at oprette en tredje, kroatisk entitet i Bosnien.

I denne situation, hvor det er meget svært at få øje på nogen form for konsekvent handling fra EU's side, er nøglen nok nabolandene Kroatien og især Serbien. I modsætning til begyndelsen af 1990'erne er ingen af disse lande på nuværende tidspunkt interesserede i en muligvis voldelig opløsning af Bosnien. Serbiens statsminister Aleksandar Vučić har, uden helt at ville kappe rebet til Dodik, gjort det meget tydeligt, at Serbien sætter pris på godt naboskab med Bosnien, og ikke ønsker en destabilisering af landet. Der er en vis ironi i, at EU's bedste håb om at forhindre Dodik - der tidligere var Vestens store anti-nationalistiske og reformistiske håb - $i$ at iværksætte en muligvis voldelig krise i Bosnien er Vučić - er en tidligere ultranationalist.

For nogle år siden bemærkede The Economist, at hvis EU ikke kom til Balkan, så kunne EU være sikker på, at Balkan ville komme til EU - i form af flygtninge, migranter og andre udfordringer. Med andre ord er et EU, der permanent holder Balkan udenfor ikke tænkeligt. Imidlertid er det flygtninge fra andre lande, der bruger Balkan som transitområde for at nå frem til EU. Efter to årtier, hvor for- holdet mellem EU og Balkan i stor grad har handlet om at overvinde den negative politiske og økonomiske arv fra kommunismen og krigene i det tidligere Jugoslavien, blev 2015 et år, hvor både Balkan og EU blev ramt af en større ekstern krise. Dette skete i form af den store strøm af flygtninge fra især Syrien, der begyndte at ankomme i løbet af foråret og sommeren. Her ser vi imidlertid den risiko, at EU misbruger Balkan til at udføre en slags politik, der ikke altid ville være tilladt i EU, for eksempel ved brug af grovere midler til at forhindre asylansøgere $i$ at bevæge sig mod EU. Den risiko og det muligvis ledsagende hykleri opfattes hurtigt af folk på Balkan, der i årevis er blevet belært om, hvordan stater i EU bør opføre sig mht. menneskerettigheder.

Samtidig er der stadigvæk tusindvis af især unge og dygtige mennesker fra Balkan, der hvert år søger lykken i EU. Balkan oplever med andre ord fortsat et brain drain. Det er præcist disse mennesker, der ofte er mest pro-europæiske, ambitiøse og højtuddannede, og som gerne skulle være med til at bygge en europæisk fremtid for deres egne lande. Men det er svært at bebrejde dem, at de rejser væk fra Balkan, når realiteten i lande som Bosnien, Makedonien og Kosovo er en ungdomsarbejdsløshed, der i lang tid har ligget over 60 pct.m og hvor politiske forbindelser frem for kvalifikationer og kompetencer er alfa og omega. Lande så som Kosovo og Bosnien bliver på sigt nok kun økonomisk bæredygtige, når de er indlemmet i det store fælles europæiske marked. 
Afslutningsvis kan det siges, at der trods alt, og i modsætning til hos befolkningerne i EU-landede, stadigvæk eksisterer ret stor tillid til EU på Balkan. Men denne tillid stammer mere fra manglende tiltro til egne politiske, økonomiske og samfundsmæssige ledere end fra tiltro til de højt besungne og efterhånden belejrede europæiske værdier. Mange mennesker anser deres hjemlige politikere som korrupte og uden ansvar over for egne borgere. I den kontekst satser mange mennesker på EU som den eneste mulighed for ekstern reform. At dette håb er skrumpet ind er ikke nødvendigvis helt dårligt. Det var aldrig godt, at EU blev betragtet - eller for den sags skyld betragtede sig selv - som et universalmiddel for regionens mange udfordrin- ger. Overoptimistiske forestillinger om EU bidrog bl.a. til en fraskrivelse af ansvar for reformer hos den enkelte borger. De vigtigste pro-europæere på Balkan i dag er dem, der har forstået, at de krav, som EU stiller til deres lande, i meget stor grad indebærer indgreb, der vil forbedre stat, samfund og økonomi og derfor føre til en bedre fremtid for hele regionen. 'Gør det ikke på grund af EU - gør det på grund af dig' selv lyder reformpolitikernes kald. EU må omvendt holde døren åben for resten af Balkan, men hele tiden gøre det klart, at medlemskab kun kan opnås gennem hårdt arbejde $\mathrm{og}$ ved at vedtage og gennemføre omfattende reformer. 